\title{
System of exercises for teaching future seafarers how to write business correspondence in English
}

\author{
N. V. Samonenko \\ National University «Odesa Maritime Academy», Odesa, Ukraine \\ Corresponding author. E-mail: samonenko.natalie@gmail.com
}

Paper received 03.02.20; Accepted for publication 16.02.20.

https://doi.org/10.31174/SEND-PP2020-221VIII89-04

\begin{abstract}
The article deals with the problem of teaching future seafarers how to write business correspondence (letters of appeal, notices, requests, orders, refusals, claims, acts) in English. The stages of the educational process (pre-contact stage, training and contact stage, professional and contact stage) are identified and the types of work at each stage are determined. The system of exercises consisting of 3 successive blocks is elaborated and introduced into practice.
\end{abstract}

Keywords: integrated teaching, business correspondence in English, system of exercises, future seafarers.

Introduction. One of the current aims of foreign language teaching is to prepare students for fruitful communication in a foreign language in different spheres of human activity. Foreign language knowledge becomes the norm of life, it largely determines the professional career of an individual. This factor is explained by the development of official contacts at the international arena, many of which occur in a written form. Navigation is one of those areas where there is a great need for highly-qualified specialists with the professional knowledge of the English language that is specially stated in the IMO "Convention on Standards of Training Certification and Watchkeeping for Seafarers" (STCW). It says: "The seafarer should know how to conduct communication in English to ensure the safety of human life and the safety of property, to reduce the risk of errors in the transmission of information" [5]. Many of such professional contacts take place in a written form providing business correspondence with the Port authorities, ship owners, marine companies' representatives, marine agents etc. That's why there is a great need for high-quality, well-structured foreign language education programmes according to the international standards in the field of written communication.

Literature Review. The problem of the English-language written competence development was researched in the works of such Ukrainian and foreign scholars as: M. Zhinkin, S. Litvin, R. Milrud, A. Minyar-Belorucheva, S. Nikolayeva, I. Nuzh, Yu. Passov, N. Sklyarenko, T. Ryazantseva, O. Tarnopolsky, T. Hedge, A. Pincas, A. Raimes, Ch. Tribble, R. White, etc. In general, the analysis of the teaching methods of English-language written business communication of students of non-linguistic specialties showed the focus of the research on: reading professionally-oriented, authentic texts and retelling them in a written form; development of skills of different types of written communication depending on the students' specialty; creation of business communicative situations for written speech interaction in conditions close to the professional ones; organization of training stages with a gradual increase in the skills of foreign-language written dialogical speech.

However, in the theory and practice of teaching students of non-linguistic specialties the English language, there is no scientifically-based methodological system for the development of English written competence of future marine specialists. In particular, there is no well-grounded system of exercises for training future seafarers how to write business correspondence in English.

Therefore, the aim of this research was to elaborate a scientifically-grounded system of exercises for training future seafarers how to write business correspondence in English.
Methods. To disclose the topic, descriptive and logical methods were used; for collection and generalization, the methods of induction and deduction, the method of comparison, analysis and synthesis of information were applied.

Results and Discussion. To start speaking about the elaborated system of exercises for training future seafarers how to write business correspondence in English it is considered reasonable to define the term "system of exercises" in general. According to N. Gez, system of exercises is understood as the organization of interrelated training activities, arranged in order of increasing speech or operational difficulties, taking into account the sequence of speech skills formation and the nature of existing speech acts [2].

The system of exercises for teaching any type of speech activity, including business correspondence of future seafarers in English, depends on many factors. They are the following: teaching objectives; elements of the major subject corresponding to the objectives; structural components of the teaching content; methodological actions, that is, exercises that ensure mastering of each component of the teaching content; learning tools that contribute to the implementation of each methodological action; control of students' mastering the elements of the major subject [6]. The above-mentioned components of the teaching process, according to I. Lerner and V. Kraevsky, are called links of the pedagogical process, which ensure the integrity and consistency of this process [3; 4]. The system of exercises is considered the main factor that ensures the practical implementation of the developed methodology and contributes to the successful mastering a foreign language.

There is a need to consider in detail the elaborated system of exercises for teaching future seafarers how to write business correspondence in English. The system is based on a three-stage process of integrated teaching, namely: precontact stage, educational and contact stage, professional and contact stage and consists of three blocks of exercises corresponding to each stage.

The aim of the pre-contact stage is preparation for business interaction - gathering and analyzing the information, as well as planning a program for future business communication between partners. At this stage, professional knowledge in a foreign language, specific terminology and professional vocabulary are acquired. At the first stage, a certain amount of vocabulary is introduced (up to 20 lexical units), which is considered "one lexical dose". Such dose allows reading and writing draft letters. This amount of vocabulary is based on the results of the research of professor G. Kharlov, who, conducting numerous experiments, proved that words for reading literary texts can be learned at the receptive level by 
repeating them 6-7 times in the process of interpreting their contents and reading different examples with these words [7]. Further research done by R. Martynova confirmed that introducing lexical units into the students' operative memory for their recognition in the texts requires approximately the same number of repetitions.

But concerning our study, we must state that for the future marine specialists it is not enough only to recognize the lexical units in the texts. Vocabulary should be used both when reading business letters and when writing them that determine the necessity to form skills of conscious use of the lexical units in phrases and sentences. It can be achieved by repeating the vocabulary ten times in oral and written forms. The formation of such skills creates the basis for the development of educational and speech skills, that means reading and writing letters expressing the main semantic content. To develop such skills, another fourteen-time repetition of the vocabulary in different kinds of language activity is required [6, p. 50].

In our case, the lexical units under study are not frequently-used in the colloquial speech. They are specific, professionally-thematic in nature. Therefore, it is not possible to reduce the fixed number of repetitions of the lexical units that allows us to consider approximately 20 lexical units avalaibale for their learning at one lesson. Such amount of vocabulary, as we noted above, provides the opportunity for the development of educational and speech skills. We can refer to them as "skills of the first level of complexity". They help to present the main content of the business communication; but at the same time they are limited to their content expression within some genres.

Thus, the first block of exercises in accordance with the pre-contact stage of training is aimed at students' acquiring knowledge of the first dose of lexical units; forming the skills of their usage in phrases and sentences; developing the educational skills of reading letters of limited content on a specific topic, for example, "Loading / Unloading a vessel" using vocabulary of dose 1; developing the educational skills in writing such letters on the topic under study using the same lexical dose.

The aim of the second training and contact stage is to implement an act of verbal or written interaction in a business context (the beginning of a contact, its development and completion). This stage supposes presenting the information in a written form as a business letter addressed to the recipient (a native speaker) in various business communication genres. Training at this stage is of a three-step process. At the first step, the educational texts of the limited content are presented and, accordingly, educational letters of the limited content are presented. At the second step, educational texts of the extended content are presented and, accordingly, educational letters of the extended content are presented. At the third step, authentic texts of professional content are presented and, accordingly, real professional letters are presented.

At this stage, the amount of lexical units is increased and the next lexical dose is introduced. Its learning occurs in the same methodical way as the learning of the vocabulary of the first dose, that means that the knowledge of these words is acquired, the skills of their use in phrases and sentences are developed, and then more complex speech skills which we can refer to as "skills of the second level of complexity" are developed. The main condition for their formation is the compulsory use of not only newly-introduced vocabulary the vocabulary of dose 2 , but also the previous dose, that is, the vocabulary of dose 1 . Their combination allows reading more complex samples of business letters that are close to the authentic variants and only partially adapted. The samples of such letters are created on the basis of those that the future seafarers will receive in response to their requests. However, the most complex linguistic phenomena which are typical in the Port authorities' correspondence are excluded from them. These may be abbreviations unknown to students, names of repair work in unfamiliar clichéd structures, non-typical forms of grammatical constructions, etc. Reading original, only partially adapted letters of extended content, provides the opportunity for the development of writing skills for independent business correspondence. But more often it occurs not in the form of an answer to any proposals of the Port authorities, but in the form of an appeal to them with specific requests or information in order to obtain permission for further professional actions. The use of the second and first doses $(2+1)$ of the vocabulary in such letters expands the possibilities of both: informing the Port authorities concerning a particular problem and using a variety of genre forms of such requests.

Thus, the exercises of the second block in accordance with the educational and contact stage are aimed at students' acquiring knowledge of the second dose of the lexical units on the same topic; forming the skills of their usage in combination with lexical units of dose 1 in phrases and sentences; developing reading skills of authentic, partially adapted letters in different genres of extended content with the use of the second and first doses $(2+1)$ of the vocabulary; developing skills of writing letters of the same level of complexity on the same topic in different genres with the use of the second and first doses $(2+1)$ of the vocabulary.

The aim of the professional and contact stage is the analysis and generalization of the results of business interaction, the implementation of decisions made during the contact, summing up the results of business conversations, as well as planning on this basis certain actions for the purpose of further cooperation. At this stage students must get a reaction to their written letter. It occurs either in the form of professional actions, or in the form of clarification of some professional circumstances by means of the language under study. Training at this stage is carried out in two steps: receptive, where the ability to understand fluently and accurately the information presented in its authentic form develops, and reproductive, where the skills of clarifying the requested information and performing relevant professional activities develop.

At this stage there is an increase of the amount of lexical units in the students' professional speech. It occurs by learning the third dose of the lexical units. These units include those linguistic phenomena that, at the previous stages, were excluded from the original letters, as well as additional, not typical vocabulary on the topic under study. The use of the third dose of the lexical units, in combination with the second and first ones $(3+2+1)$ does not allow forgetting the material which was learned before, and also provides the ability to read samples of the authentic, non-adapted letters of different genres. The examples of such letters are the letters of appeal to the Port authorities, written by native speakers, as well as the answers to them given by real participants of the professional marine activities.

A detailed study of these authentic letters, their discussion and interpretation of their contents, allows students writing their own samples of letters of appeal to the Port authorities 
based on the real professional circumstances arisen on board the ship. Thus, the "skills of the third level of complexity" (the highest ones) are developed, and the lexical competence of future seafarers, which is defined as "the ability of individuals to operate with knowledge of the English vocabulary (common and professional words, terms, phrases, setexpressions, idioms, phrasal verbs, formulas of speech etiquette) and understand the lexical norms of its application; to have both the skills of understanding and reproducing this vocabulary in phrases / sentences / texts and the skills of receptive-reproductive and productive skills of fluent operation of this vocabulary in the process of writing, reading, listening and speaking" $[1$, p. 35] is formed.

Thus, the exercises of the third block in accordance with the professional and contact stage are aimed at students' acquiring knowledge of the vocabulary of dose 3 on the same topic; developing skills in using vocabulary of dose 3 in combination with the vocabulary of doses $2+1$ in phrases and sentences; developing reading skills of authentic, nonadapted letters of different genres, for example, an authentic letter to the port authorities "Notification of the vessel readiness for cargo loading", including vocabulary of doses $3+2$ +1 ; developing writing skills on the same topic, caused by real, professional problems, for example, in the genre of "request", in the genre of "act", in the genre of "claim" using the vocabulary of doses $3+2+1$, taking into account unforeseen circumstances. The following assignments are given as the examples of such letters. 1. The task is: to write a business letter in the genre of "request" to contact the Port authorities for the following reasons: a) to arrange loading / unloading of heavy containers; b) to order an additional crew of movers for overtime work in the port; c) to send a representative of the shipper to measure the cargo after loading. Exchange these letters and write the supposed answers of the Port authorities. 2. The task is: to write a business letter in the genre of "act": contact the Port authorities in writing to inform them: a) of the repair of the damage which was done to the vessel during the cargo operations; $b$ ) of the refusal of the consignor to deliver the goods within the established time limits according to the Charter; c) of the organization of the tallymen's work for re-counting cargo at the port. 3 . The task is: to write a business letter in the genre of "claim": contact the Port authorities in writing: a) on compensation for losses caused by the vessel demurrage; $b$ ) on reduction the rate of unloading at the request of the consignee; c) on rejection of possible claims for containers damage during their unloading by coastal facilities.

Conclusions. In the course of the study, we came to the following conclusions. The stages for teaching future seafarers how to write business correspondence in English are the following: pre-contact stage, training and contact stage, professional and contact stage; at each stage a special block of exercises is implemented. The first block of exercises is aimed at students' acquiring the knowledge of the lexical units of dose 1; forming the skills of their usage in phrases and sentences; developing the educational skills of reading letters of limited content on a specific topic in some genres using the vocabulary under study; developing the educational skills in writing such letters on the topic under study using the same lexical dose. The second block of exercises is aimed at students' acquiring the knowledge of the second dose of lexical units on the same topic; forming the skills of their usage in combination with lexical units of dose 1 in phrases and sentences; developing reading skills of authentic, partially adapted letters in different genres of extended content with the use of vocabulary of doses of $2+1$; developing skills of writing letters of the same level of complexity on the same topic in different genres with the use of vocabulary of doses of $2+1$. The third block of exercises is aimed at students' acquiring the knowledge of the vocabulary of dose 3 on the same topic; forming the skills in using vocabulary of dose 3 in combination with the vocabulary of doses $2+1$ in phrases and sentences; developing reading skills of authentic, non-adapted letters of different genres, including vocabulary of doses $3+2+1$; developing skills of writing on the same topic, caused by real, professional problems using vocabulary of doses $3+2+1$, taking into account unforeseen circumstances. Thus, the stated results of the study provide ithe basis for the development of a complete linguodidactic model for teaching future navigators how to write business correspondence in English with its entire links and its practical implementation.

\section{ЛИТЕРАТУРА}

1. Боднар С. В. Когнітивний підхід до формування англомовної лексичної компетентності студентів економічних спеціальностей. Наука $і$ освіта : науково-практичний журнал. Одеса : Південний науковий центр НАПН України, 2014. №10/CXXVII. C. 34-38.

2. Гез Н. И. Система упражнений и последовательность развития речевых умений и навыков. Иностранные языки в школе. 1969. № 6. С. 29-40.

3. Краевский В. В. Полонский В. М. Методология для педагога: теория и практика. Волгоград: Перемена, 2001. 324 с.

4. Лернер И. Я. Процесс обучения и его закономерности. М.: Знание, $1980.96 \mathrm{c}$.

5. Международная конвенция о подготовке и дипломировании моряков и несении вахты 1978 г., измененная конференцией 1995 г. Санкт-Петербург : ЗЛО НИИМФ, 1996. 551 с.

6. Мартинова Р.Ю. Цілісна загальнометодична модель навчання іноземних мов: [монографія]. К.: Вищашк., 2004.454c.

7. Харлов Г. А. Основы системного обучения иноязычному лексическому материалу при чтении текстов в неязыковом вузе: дисс. ... доктора пед. наук 13.00.02. Одесса, 1991. 339с.

\section{REFERENCE}

1. Bodnar, S.V. Cognitive approach to the formation of Englishspeaking lexical competence of students of economic specialties//Science and education: a scientific and practical journal. Odessa: Southern Scientific Center of the National Academy of Pedagogical Sciences of Ukraine, 2014. №10/ CXXVII, p.34-38.

2. Gez, N. I. System of exercises and sequence of development of speech skills//Foreign languages at school, 1969. № 6, p. 29-40.

3. Kraevsky, V.V., Polonsky, V. M. Methodology for the teacher: theory and practice. Volgograd: Changes, 2001. 324 p.

4. Lerner, I. Ya. The learning process and its regularities. M .: Knowledge, $1980.96 \mathrm{p}$.

5. International Convention on Standards of Training Certification and Watchkeeping for Seafarers, 1978, amended by the 1995 conference.

http://www.imo.org/en/About/Conventions/ListOfConventions/P ages/International-Convention-on-Standards-of-Training,-Certification-and-Watchkeeping-for-Seafarers-(STCW).aspx.

6. Martinova, R.Yu. A Comprehensive Methodological Model of Foreign Language Teaching: [monograph]. K.: Higher School, 2004. 454 p.

7. Kharlov, G. A. Fundamentals of systematic teaching of foreignlanguage lexical material when reading texts in a non-linguistic University: Doctoral thesis, Odessa, 1991. 339 p. 